H.D. Siregar dan Motlan: Pengaruh Model Pembelajaran

Jurnal Pendidikan Fisika

Kooperatif Group Investigation dan Pemahaman p-ISSN2252-732X

Konsep Awal Terhadap Keterampilan Proses Sains

e-ISSN 2301-7651

Siswa SMA

PENGARUH MODEL PEMBELAJARAN KOOPERATIF GROUP INVESTIGATION DAN PEMAHAMAN KONSEP AWAL TERHADAP KETERAMPILAN PROSES SAINS SISWA SMA

\author{
Hiba Dertyana Siregar ${ }^{1}$ dan Motlan ${ }^{2}$ \\ ${ }^{1}$ Alumni Mahasiswa Program Studi Pendidikan Fisika Program \\ Pascasarjana UNIMED \\ ${ }^{2}$ Program Studi Pendidikan Fisika Program Pascasarjana UNIMED \\ email:hibadertyana@gmail.com
}

\begin{abstract}
Abstrak. Penelitian ini bertujuan untuk mengetahui: perbedaan keterampilan proses sains siswa yang menggunakan model pembelajaran kooperatif group investigation dengan model pembelajaran direct instruction. Penelitian ini merupakan penelitian quasi eksperimen. Sampel dalam penelitian ini dilakukan dengan teknik cluster random sampling. Instrumen yang digunakan dalam penelitian ini adalah tes pemahaman konsep awal dalam bentuk pilihan ganda yang terdiri dari 10 soal dan tes keterampilan proses sains dalam bentuk pilihan ganda sebanyak 15 soal. Dari hasil penelitian dapat disimpulkan bahwa: 1) ada perbedaan keterampilan proses sains siswa yang diajarkan dengan menggunakan model pembelajaran kooperatif group investigation, 2) ada perbedaan keterampilan proses sains siswa yang memiliki pemahaman konsep awal tinggi dan rendah, 3) terdapat interaksi antara model pembelajaran kooperatif group investigation dan pemahaman konsep awal terhadap keterampilan proses sains siswa.
\end{abstract}

Katakunci: kooperatif group investigation, pemahaman konsep awal, keterampilan proses sains.

\title{
THE EFFECT OF KOOPERATIF LEARNING MODEL TYPE GROUP INVESTIGATION AND FIRST CONCEPT UNDERSTANDING TO SCIENCE PROCESS SKILL OF SENIOR HIGH SCHOOL STUDENT
}

\author{
Hiba Dertyana Siregar ${ }^{1}$ and Motlan ${ }^{2}$ \\ ${ }^{1}$ Student Alumni of Physics Education Study Programs Postgraduate \\ School UNIMED \\ ${ }^{2}$ Physics Education Study Programs Postgraduate School UNIMED \\ email:hibadertyana@gmail.com
}

\begin{abstract}
This study aims to: know the difference science process skills of students using cooperative learning model group investigation with direct instruction teaching model. This study is quasi exsperiment. The sample in this research was done by using cluster random sampling two classes. Instruments used in this research is understanding the concept of the initial test in the form of multiple-choice comprised of 10 questions and test science process skills in the form of 15 questions of multiple choice. From the results
\end{abstract}




\section{H.D. Siregar dan Motlan: Pengaruh Model Pembelajaran Kooperatif Group Investigation dan Pemahaman Konsep Awal Terhadap Keterampilan Proses Sains Siswa SMA}

Jurnal Pendidikan Fisika
p-ISSN2252-732X
e-ISSN 2301-7651

of this study concluded that: 1) there are differences in students' science process skills are taught using cooperative learning model group investigation, 2) there is a difference science process skills of students who have an understanding of the concept of high and low initial, 3) there is an interaction between the model of cooperative learning group investigation and understanding of the initial concept of the science process skills that students have a better learning model applied to students who have an understanding of the high initial concept.

\section{Keywords: Cooperatif Group Investigation, Pre-Concept Understanding, Science Process Skills}

\section{PENDAHULUAN}

Upaya untuk memperbaiki dan meningkatkan pendidikan seakan tidak pernah berhenti. Beragam program inovatif seperti pengembangan kompetensi guru, pengembangan kurikulum, pengelolaan pembelajaran dan pengembangan bahan ajar dan masih banyak hal yang telah dilakukan untuk menjadikan pendidikan di Indonesia semakin baik.Salah satu tujuan pembelajaran yang penting adalah membantu peserta didik dalam memahami konsep utama dalam suatu subyek, bukan sekedar mengingat fakta yang terpisah-pisah. Sebagian besar dari proses perkembangan berlangsung melalui kegiatan belajar. Proses pembelajaran di kelas harus dapat mengembangkan cara belajar peserta didik untuk mendapatkan, mengelola, menggunakan dan mengkomunikasikan apa yang telah diperoleh dalam proses belajar tersebut. (Suryosubroto, 2002: 71).

Survei yang dilakukan oleh Programme for International Student Assessment (PISA) tahun 2009 untuk tingkat pencapaian sains, Indonesia berada diperingkat 60 dari 65 negara sebagai peserta yang mengikuti studi PISA. (Tim PISA Indonesia, 2011). Di tahun 2012, Indonesia kembali menjadi peserta dalam PISA. Dari hasil survei tersebut untuk bidang sains, Indonesia berada di urutan 64 . Jika dibandingkan dengan tahun sebelumnya, di tahun 2012 ini Indonesia mengalami kemunduran. (Giyato, 2013).Berdasarkan hasil wawancara yang tidak terstruktur yang dilakukan peneliti pada guru bidang studi fisika di salah satu SMA di Medan tanggal 09 Februari 2014 diperoleh bahwa banyak kendala yang sering ditemui selama proses pembelajaran fisika berlangsung, antara lain daya tangkap siswa yang terbatas serta berbeda-beda dan penguasaan konsep fisika siswa yang masih kurang baik. Untuk pembelajaran di dalam kelas ada siswa yang aktif dan masih ada juga siswa yang kurang aktif.

Sains dan pembelajarannya tidak hanya sekedar pengetahuan yang bersifat ilmiah saja, tetapi terdapat juga dimensi-dimensi ilmiah yang penting lainnya. Dimensi pertama adalah muatan sains (content of science) yang secara keseluruhan terarah baik kognitif maupun psikomotor yang menemukan suatu fakta, konsep, hukum dan teori. Dimensi inilah yang menjadi obyek kajian ilmiah manusia. Dimensi kedua adalah proses dalam melakukan aktivitas ilmiah dan sikap ilmiah dari aktivis sains. Proses dalam melakukan aktivitas-aktivitas yang terkait dengan sains inilah yang disebut dengan keterampilan proses sains (science proccess skills). Keterampilan proses ini melibatkan kognitif, manual dan sosial. Keterampilan proses ini digunakan para ilmuwan ketika mengerjakan aktivitas-aktivitas sains. Karena sains adalah tentang mengajukan pertanyaan dan mencari jawaban dari pertanyaan-pertanyaan yang diajukan, maka keterampilan ini dapat juga diterapkan dalam kehidupan kita sehari-hari ketika kita menemukan persoalanpersoalan keseharian dan kita harus mencari jawabannya. Jadi, mengajarkan keterampilan proses sains pada siswa sama artinya dengan mengajarkan keterampilan yang nantinya akan mereka gunakan dalam kehidupan keseharian mereka.

Belajar pengetahuan meliputi tiga fase, yaitu: (1) fase eksplorasi, dimana peserta didik mempelajari gejala dengan bimbingan, (2) fase pengenalan konsep, dimana peserta didik mengenal konsep yang ada hubungannya dengan gejala, dan (3) fase aplikasi konsep, dimana peserta didik menggunakan konsep untuk meneliti gejala lain lebih lanjut. (Dimyati dan Mudjiono, 2009: 14).

Keterampilan proses sains memiliki peran penting dalam menemukan konsep sains. Konsep merupakan salah satu pengetahuan awal yang harus dimiliki oleh siswa karena konsep merupakan dasar dalam merumuskan prinsip artinya untuk dapat menguasai prinsip dan teori harus dikuasai terlebih dahulu konsep-konsep yang menyusun prinsip dan teori yang bersangkutan. Harlen dan Elstgeest (1992: 50) menyatakan bahwa keterampilan proses sains adalah keterampilan fisik dan mental terkait dengan kemampuan-kemampuan yang mendasar yang dimiliki, dikuasai dan diaplikasikan dalam suatu kegiatan ilmiah, sehingga para ilmuan berhasil menemukan sesuatu yang baru.Gega (1994: 102) mengemukakan bahwa keterampilan proses sains adalah alat yang memungkinkan peserta didik untuk mengumpulkan data untuk diri mereka sendiri yang meliputi mengamati, mengklasifikasi, mengukur, berkomunikasi, menyimpulkan dan memprediksi, bereksperimen. Untuk mengajarkan proses, kita harus mengajak peserta didik melakukan penyelidiki dari berbagai konteks subyek dan membimbing pemikiran 
H.D.Siregar dan Motlan: Pengaruh Model Pembelajaran

Jurnal Pendidikan Fisika

p-ISSN2252-732X

Kooperatif Group Investigation dan Pemahaman

Konsep Awal Terhadap Keterampilan Proses Sains

e-ISSN 2301-7651

Siswa SMA

mereka dengan pertanyaan yang luas dan sempit yang menunjuk setiap prosesnya.

Pemahaman konsep yang baik akan membantu

pemakaian konsep-konsep yang lebih kompleks. Pemahaman konsep merupakan kemampuan siswa menguasai materi pelajaran yang diberikan. Ada dua cara yang dapat digunakan untuk mengamati dan memperoleh informasi yang digunakan peserta didik untuk mencapai konsep, yaitu: (1) setelah suatu konsep dicapai, kita dapat meminta mereka untuk menceritakan pemikirannya agar latihan terus berlangsung, (2) kita dapat meminta siswa untuk menuliskan hipotesis mereka. (Joyce et.al, 2011: 133). Group investigation merupakan salah satu model pembelajaran kooperatif dimana para peserta didik secara kolaboratif dalam kelompoknya memeriksa, mengalami dan memahami topik kajian yang akan dipelajari. Model ini memiliki manfaat untuk melatih peserta didik untuk menerima perbedaan pendapat dan bekerja dalam melakukan penyelidikan untuk memecahkan masalah bersama-sama dengan peserta didik lain yang berbeda latar belakangnya.Slavin (2005: 215) mengemukan bahwa komunikasi dan interaksi kooperatif di antara sesama teman sekelas akan mencapai hasil terbaik apabila dilakukan dalam kelompok kecil.

\section{METODE PENELITIAN}

Penelitian ini dilaksanakan di kelas X semester I di SMA Methodist 8 Medan. Pengambilan sampel dilakukan dengan cara cluster random sampling dimana sampel tersebut dibagi menjadi dua kelas yaitu kelas eksperimen diajarkan dengan model pembelajaran kooperatif group investigation dan kelas kontrol dengan menggunakan model pembelajaran direct instruction. Adapun desain penelitian untuk ANAVA 2 x 2 dapat dilihat pada Tabel 1.

\section{HASIL DAN PEMBAHASAN}

Hasil penelitian meliputi data (1) tes pemahaman konsep awal dan (2) tes keterampilan proses sains. Pada tahapan penelitian, kelas eksperimen dan kelas kontrol diberikan pretes keterampilan proses sains (KPS) dan tes pemahaman konsep awal (PKA). Berdasarkan pretes yang dilakukan diperoleh nilai rata-rata kelas kontrol sebesar 41,44 dan nilai rata-rata kelas eksperimen sebesar 43,60. Dari data pretes tersebut dilakukan uji kesamaan rata-rata dilakukan uji normalitas dan uji homogenitas untuk melihat kemampuan awal siswa. Pengujian dilakukan dengan menggunakan SPSS statistics 19 dengan independent sample t-test. Data tersebut diuji normalitas dan homogenitasnya terdahulu, hasilnya seperti yang ditunjukkan pada Tabel 2. Hasil uji homogenitas dengan menguunakan SPSS statistics 19 dari kedua kelas dapat dilihat pada Tabel 3. Setelah mengetahui data pretes berdistribusi normal dan homogennya selanjutnya data diuji menggunakan uji kesamaan varians dan rata-rata pretes. Hasil uji kesamaan rata-rata varians dapat dilihat pada Tabel 4.

Berdasarkan Tabel 4 diperoleh pengujian uji $t$ sebesar $-0,735$ dengan taraf signifikansi 0,465 . Hasil ini menunjukkan bahwa nilai signifikansi lebih besar daripada taraf signifikan 0,05. Sehingga dapat disimpulkan bahwa tidak ada perbedaan nilai pretes kelas kontrol dengan kelas eksperimen. Hal ini menunjukkan kedua kelas memiliki kemampuan awal yang sama.

Selain hasil penelitian berupa keterampilan proses sains, deskripsi hasil juga memuat data pemahaman konsep awal (PKA) sebagai variabel moderator. Dari data tersebut, yaitu kelompok siswa dengan tingkat pemahaman konsep awal tinggi (diatas rata-rata) dan pemahaman konsep awal rendah (dibawah rata-rata). Analisis menunjukkakelompok PKA tinggi dan PKA rendah kelas eksperimen berturut-turut sejumlah 18 orang dan 19 orang. Sedangkan kelompok PKA tinggi dan PKA rendah kelas kontrol berturut-turut sejumlah 17 orang dan 20 orang. Pemahaman konsep awal tinggi pada kelas kontrol menunjukkan rata-rata sebesar 57,64 sementara pada kelas eksperimen sebesar 66,67. Pemahaman konsep awal rendah pada kelas kontrol menunjukkan rata-rata sebesar 32,50 dan pada kelas eksperimen sebesar 36,31. Dari data tersebut dapat disimpulkan bahwa untuk pemahaman konsep awal tinggi maupun rendah, nilai rata-rata kelas eksperimen lebih besar dibandingkan dengan kelas kontrol. Keterampilan proses sains siswa dapat dikelompokkan berdasarkan tingkat pemahaman konsep awal yang dimiliki oleh siswa pada kelas kontrol dan kelas eksperimen. Untuk lebih jelasnya mengenai keterampilan proses sains berdasarkan pemahaman konsep awal dapat dilihat pada Tabel 5. Secara ringkas, analisis nilai keterampilan proses sains siswa berdasarkan pemahaman konsep awal dapat dilihat pada Gambar 1. Analisis keterampilan proses sains siswa setelah pembelajaran berdasarkan pemahaman konsep awal dapat dilihat pada Tabel 6. Setelah pengelompokan siswa dilakukan, maka dilakukan uji hipotesis dengan menggunakan ANAVA dua jalur seperti yang ditunjukkan pada Tabel 7.

Hasil temuan dalam penelitian ini menunjukkan bahwa ada perbedaan keterampilan proses sains siswa menggunakan model pembelajaran kooperatif group investigation dengan model pembelajaran direct instruction, dimana rata-rata keterampilan proses sains siswa pada kelas eksperimen lebih tinggi daripada kelas kontrol. Hasil yang signifikan dalam penelitian ini bisa disebabkan karena aktivitas pembelajaran kooperatif group investigation mengajak siswa untuk bekerja sama dan berinteraksi dalam kelompok serta mengajak siswa untuk lebih aktif dalam proses pembelajaran. Tidak hanya bekerja sama, dalam proses pembelajaran juga para siswa saling melakukan pertukaran ide dan pengetahuan dalam kelompok yang terbentuk secara heterogen. Kelompok juga dijadikan sebagai sarana sosial dalam proses pembelajaran. Rencana kelompok adalah suatu metode untuk mendorong keterlibatan maksimal dari masingmasing siswa. 
H.D.Siregar dan Motlan: Pengaruh Model Pembelajaran

Tabel 1 Desain Penelitian ANAVA

\begin{tabular}{|l|c|c|c|}
\hline \multicolumn{1}{|c|}{ Kelas (A) } & $\begin{array}{c}\text { Kelas } \\
\text { Eksperimen (1) }\end{array}$ & $\begin{array}{c}\text { Kelas } \\
\text { Kontrol (2) }\end{array}$ & $\begin{array}{c}\text { Rata- } \\
\text { rata }\end{array}$ \\
\hline Pemahaman Konsep Awal (B) & $\mu_{1}$ & $\mu_{2}$ & $\mu_{T}$ \\
\hline Rendah (2) & $\mu_{1}$ & $\mu_{2}$ & $\mu_{R}$ \\
\hline Rata-rata & $\mu_{E}$ & $\mu_{K}$ & \\
\hline
\end{tabular}

Keterangan:

$\mu_{1}$ : Nilai rata-rata siswa yang diajar dengan model pembelajaran kooperatif group investigation dengan pemahaman konsep awal tinggi.

$\mu_{1}$ : Nilai rata-rata siswa menggunakan model pembelajaran kooperatif group investigation dengan pemahaman konsep awal rendah.

$\mu_{2}$ : Nilai rata-rata siswa menggunakan model direct instruction dengan pemahaman konsep awal tinggi.

$\mu_{2}$ : Nilai rata-rata siswa menggunakan model direct instruction dengan pemahaman konsep awal rendah.

$\mu_{t} \quad$ : Nilai rata-rata kelas eksperimen.

$\mu_{K} \quad$ : Nilai rata-rata kelas kontrol.

$\mu_{K}$ : Nilai rata-rata pemahaman konsep awal rendah.

$\mu_{T}$ : Nilai rata-rata pemahaman konsep awal tinggi.

Tabel 2. Uji Normalitas Data Pretes

\begin{tabular}{|l|r|r|r|}
\hline \multirow{2}{*}{ Model } & \multicolumn{3}{|c|}{ Kolmogorov-Smirnov } \\
\cline { 2 - 4 } & Statistik & dk & Sig. \\
\hline $\begin{array}{l}\text { Direct } \\
\text { Instruction }\end{array}$ &, 129 & 37 &, 121 \\
\hline $\begin{array}{l}\text { Group } \\
\text { Investigation }\end{array}$ &, 131 & 37 &, 110 \\
\hline \multicolumn{3}{|l|}{ a. Signifikansi Lilliefors } \\
\hline
\end{tabular}

Tabel 3. Uji Homogenitas Data Pretes

\begin{tabular}{|r|r|r|r|}
\hline $\begin{array}{c}\text { Levene } \\
\text { Statistic }\end{array}$ & dk1 & dk2 & Sig. \\
\hline 0,676 & 1 & 72 &, 414 \\
\hline
\end{tabular}

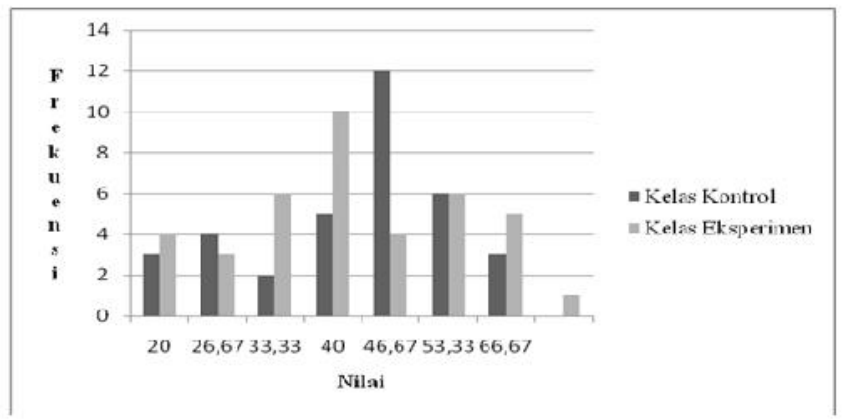

Gambar 1. Data Keterampilan Proses Sains Siswa Berdasarkan Pemahaman Konsep Awal 
H.D.Siregar dan Motlan: Pengaruh Model Pembelajaran

Kooperatif Group Investigation dan Pemahaman p-ISSN2252-732X

Konsep Awal Terhadap Keterampilan Proses Sains

Tabel 4. Uji Kesamaan Rata-rata Data Pretes

\begin{tabular}{|l|c|c|c|c|r|}
\hline & \multicolumn{5}{|c|}{ Uji $t$ untuk Kesamaan Rata-rata } \\
\cline { 2 - 6 } & T & Dk & Sig. & $\begin{array}{c}\text { Beda } \\
\text { Rata- } \\
\text { rata }\end{array}$ & $\begin{array}{c}\text { Beda Std. } \\
\text { Kesalahan }\end{array}$ \\
\hline $\begin{array}{l}\text { Kesamaan rata-rata } \\
\text { yang diasumsikan }\end{array}$ &,- 735 & 72 &, 465 & $-2,162$ & 2,942 \\
\hline $\begin{array}{l}\text { Kesamaan rata-rata } \\
\text { yang tidak } \\
\text { diasumsikan }\end{array}$ &,- 735 & 70,992 &, 465 & $-2,162$ & 2,942 \\
\hline
\end{tabular}

Tabel 5. Keterampilan Proses Sains Siswa berdasarkan Pemahaman Konsep Awal

\begin{tabular}{|c|c|c|c|c|c|}
\hline \multicolumn{3}{|c|}{ Pemahaman Konsep Awal Tinggi } & \multicolumn{3}{|c|}{ Pemahaman Konsep Awal Rendah } \\
\hline KPS & Frekuensi & Rata-rata & KPS & Frekuensi & Rata-rata \\
\hline 20 & 3 & \multirow{8}{*}{43,24} & 20 & 4 & \multirow{8}{*}{41,88} \\
\hline 26,67 & 4 & & 26,67 & 3 & \\
\hline 33,33 & 2 & & 33,33 & 6 & \\
\hline 40 & 5 & & 40 & 10 & \\
\hline 46,67 & 12 & & 46,67 & 4 & \\
\hline 53,33 & 6 & & 53,33 & 6 & \\
\hline \multirow{2}{*}{66,67} & \multirow{2}{*}{3} & & 60 & 5 & \\
\hline & & & 66,67 & 1 & \\
\hline
\end{tabular}

Keterangan:

KPS : keterampilan proses sains siswa

Tabel 6. Statistik ANAVA

\begin{tabular}{|l|l|c|r|r|}
\hline \multicolumn{1}{|c|}{ Model } & \multicolumn{1}{|c|}{$\begin{array}{c}\text { Pemahaman } \\
\text { Konsep Awal }\end{array}$} & $\begin{array}{c}\text { Rata- } \\
\text { rata }\end{array}$ & $\begin{array}{c}\text { Std. } \\
\text { Deviasi }\end{array}$ & N \\
\hline \multirow{2}{*}{$\begin{array}{l}\text { Direct } \\
\text { Instruction }\end{array}$} & Tinggi & 72,27 & 22,393 & 17 \\
\cline { 2 - 5 } & Rendah & 61,02 & 24,069 & 20 \\
\cline { 2 - 5 } & Total & 65,95 & 30,490 & 37 \\
\hline \multirow{3}{*}{$\begin{array}{l}\text { Group } \\
\text { Investigation }\end{array}$} & Tinggi & 83,80 & 28,641 & 18 \\
\cline { 2 - 5 } & Rendah & 66,32 & 26,729 & 19 \\
\cline { 2 - 5 } & Total & 74,77 & 49,330 & 37 \\
\hline \multirow{3}{*}{ Total } & Tinggi & 79,61 & 34,438 & 35 \\
\cline { 2 - 5 } & Rendah & 64,38 & 27,216 & 39 \\
\cline { 2 - 5 } & Total & 71,62 & 43,940 & 74 \\
\hline
\end{tabular}

Tabel 7. Hasil Perhitungan ANAVA Dua Jalur

\begin{tabular}{|l|c|c|c|c|c|}
\hline \multicolumn{1}{|c|}{ Variabel } & $\begin{array}{c}\text { Jumlah } \\
\text { kuadrat }\end{array}$ & Dk & $\begin{array}{c}\text { Kuadrat Rata- } \\
\text { rata }\end{array}$ & F & Sig. \\
\hline Model & 20521,452 & 1 & 20521,452 & 31,340 &, 000 \\
\hline $\begin{array}{l}\text { Pemahaman } \\
\text { Konsep Awal }\end{array}$ & 59846,320 & 1 & 59846,320 & 91,397 &, 000 \\
\hline $\begin{array}{l}\text { Model* } \\
\text { Pemahaman } \\
\text { Konsep Awal }\end{array}$ & 2814,715 & 1 & 2814,715 & 4,299 &, 042 \\
\hline
\end{tabular}


H.D.Siregar dan Motlan: Pengaruh Model Pembelajaran

Jurnal Pendidikan Fisika

p-ISSN2252-732X

Kooperatif Group Investigation dan Pemahaman

Konsep Awal Terhadap Keterampilan Proses Sains

e-ISSN 2301-7651

Siswa SMA

Lingkungan pembelajaran yang konstruktivis mengubah fokus dari penyebaran informasi oleh guru, yang mendorong peran pasif siswa menuju otonomi dan refleksi siswa yang mendorong peran aktif siswa. (Jacobsen, 2009: 9). Lingkungan pembelajaran konstruktivis mengubah fokus dari penyebaran informasi oleh guru, yang mendorong peran pasif siswa menuju otonomi dan refleksi siswa yang mendorong peran aktif siswa. (Jacobsen, 2009: 9).

Hasil yang diperoleh dalam penelitian ini menunjukkan ada perbedaan yang signifikan keterampilan proses sains siswa antara kelompok siswa yang memiliki pemahaman konsep awal tinggi dan rendah. Selain itu, dari analisis rata-rata hasil keterampilan proses sains pada kelompok pemahaman konsep awal tinggi pada kelas eksperimen memiliki nilai yang lebih tinggi jika dibandingkan dengan siswa yang memiliki pemahaman konsep awal rendah pada kelas kontrol. Begitu juga untuk rata-rata nilai kelompok pemahaman konsep rendah pada kelas eksperimen lebih tinggi daripada kelas kontrol.

Tingginya pemahaman konsep ini bisa disebabkan karena siswa memiliki pemahaman konsep awal sebelumnya yang ada dalam dirinya. Keterampilan ilmiah dan sikap ilmiah memiliki peran untuk mendapatkan konsep sains. Rustaman (2005: 53) menyatakan kekuatan suatu konsep ditentukan oleh sejauh mana siswa setuju bahwa konsep itu penting dipelajari. Keterlibatan siswa akan meningkatkan pemahaman siswa terhadap konsep fisika yang mereka pelajari seperti yang dinyatakan oleh Witherington dan Burton (Djamarah, 2006: 61) the process of learning is doing, reacting, undergoing, experiencing. The products of learning are all achieved ny the learner through his own activity. Artinya, produk dari belajar itu diperoleh oleh peserta didik melalui aktivitas. Rizal (2014) menyimpulkan bahwa keterampilan proses sains siswa berkolerasi positif dengan penguasaan konsep IPA yang artinya perubahan yang terjadi pada keterampilan proses sains diikuti secara positif oleh perubahan penguasaan konsep. Panggabean (2012) menyatakan bahwa apabila pada dasarnya siswa telah memiliki pemahaman konsep yang tinggi maka akan menghasilkan kemampuan berpikir kritis yang tinggi. Hal ini senada dengan penelitian Panjaitan (2012) menyatakan bahwa kemampan pemecahan masalah fisika yang memiliki pemahaman konsep tinggi lebih baik dibandingkan siswa yang memiliki pemahaman konsep rendah. Dwi (2013) dalam penelitiannya menunjukkan terdapat perbedaan pemahaman konsep yang signifikan. Hal tersebut diperoleh karena adanya tahapan-tahapan dalam model pembelajaran yang berbasis ICT.

Hasil pengujian dengan uji Scheffe dalam melihat interaksi model pembelajaran dengan pemahaman konsep awal terhadap keterampilan proses sains siswa diperoleh hasil yang signifikan. Terdapat interaksi dalam penelitian ini bisa disebabkan karena pemahaman konsep awal yang telah dimiliki oleh siswa. Berdasarkan hasil penelitian diperoleh bahwa terdapat interaksi antara model pembelajaran kooperatif group investigation dan

pemahaman konsep awal dalam mempengaruhi keterampilan proses sains siswa. Hal ini sesuai dengan hasil perolehan secara statistik yaitu $F_{\text {hitung }}=4,299$ dengan taraf signifikansi 0,042 lebih kecil dari taraf signifikansi 0,05 . Temuan penelitian ini sejalan dengan hasil penelitian yang telah dilakukan oleh Primarinda (2012) yang menunjukkan bahwa model pembelajaran cooperative tipe group investigation (GI) berpengaruh terhadap keterampilan proses sains siswa kelas X SMA Negeri 4 Surakarta. Selain itu, Ulfah (2014) menyatakan terdapat perbedaan keterampilan proses sains sebelum dan sesudah diajarkan dengan menggunakan model pembelajaran kooperatif tipe group investigation.

Mitchell, et.all (2008: 394) menyatakan bahwa group investigation memberikan kesempatan kepada siswa untuk menemukan kepemilikan pengetahuan dan pemahaman mereka sendiri. Wiranata, I., dkk (2013:1) menyimpulkan bahwa terdapat perbedaan keterampilan proses sains siswa yang belajar dengan model pembelajaran kooperatif tipe GI dengan siswa yang belajar secara konvensional.

Interaksi antara model pembelajaran kooperatif group investigation dan model pembelajaran direct instruction dengan pemahaman konsep awal terhadap keterampilan proses sains terlihat dari grafik interaksi uji hipotesis yang menyimpulkan bahwa model pembelajaran kooperatif group investigation cocok diterapkan pada siswa yang memiliki pemahaman konsep awal tinggi. Pemahaman konsep sangat penting dalam pembelajaran karena kekeliruan dalam pemahaman konsep akan menyebabkan kesulitan dalam mempelajari materi yang akan dipelajari. Pemahaman konsep merupakan salah satu bentuk hasil dari pembelajaran yang diperoleh siswa dari mengikuti proses pembelajaran. Keterampilan proses sains sangat penting dimiliki oleh siswa dalam mengembangkan metode ilmiah dan pemahaman sains. Kemampuan keterampilan proses sains dimiliki oleh siswa dengan menggunakan konsep dan prinsip yang baik. (Delismar, 2013).

\section{SIMPULAN}

Berdasarkan hasil penelitian dan pembahasan, maka dapat disimpulkan: 1) ada perbedaan keterampilan proses sains siswa yang diajarkan dengan menggunakan model pembelajaran kooperatif group investigation dengan model pembelajaran direct instruction. Keterampilan proses sains siswa yang diajarkan dengan menggunakan model pembelajaran kooperatif group investigation lebih baik dibandingkan dengan model pembelajaran direct instruction, 2) ada perbedaan keterampilan proses sains siswa yang memiliki pemahaman konsep awal rendah dan pemahaman konsep awal tinggi. Keterampilan proses sains kelompok siswa yang memiliki pemahaman konsep awal tinggi lebih baik dari keterampilan proses sains kelompok siswa yang memiliki pemahaman konsep rendah, dan 3) ada interaksi antara model pembelajaran kooperatif group investigation dan pemahaman konsep awal dalam meningkatkan keterampilan proses sains siswa. 
H.D.Siregar dan Motlan: Pengaruh Model Pembelajaran

Jurnal Pendidikan Fisika Kooperatif Group Investigation dan Pemahaman Konsep Awal Terhadap Keterampilan Proses Sains p-ISSN2252-732X Siswa SMA

\section{REFERENCES}

Delismar. 2013. Peningkatan Kreativitas dan Keterampilan Proses Sains Siswa Melalui Penerapan Model Group Investigation. Jurnal Edu-Sains Vol.1 No. 2.

Dimyati dan Mudjiono. 2009. Belajar dan Pembelajaran. Jakarta: Rineka Cipta.

Dwi, I. M., Arif, H., \& Sentot, K. 2013. Pengaruh Strategi Problem Based Learning Berbasis ICT Terhadap Pemahaman Konsep dan Kemampuan Pemecahan Masalah Fisika. Jurnal Pendidikan Fisika Indonesia Vol. 9 Hal. 8-17ISSN1693-1246.

Gega, P. C. 1994. How To Teach Elementary School Science. New York: Macmillan Publishing Company.

Giyato. 2013. Implementasi Kurikulum 2013. http://m.suaramerdeka.com. Diakses pada 28 Desember 2013.

Jacobsen, D. A., Eggen, P., \& Kauchak, D. 2009. Methods for Teaching Edisi kedelapan. Yokyakarta: Pustaka Pelajar. Mitchell, M., et.all. 2008. Group Investigation as a Cooperative Learning Strategy: An Integrated Analysis of the Literature. The Alberta Journal of Educational Research Volume 54 No. 4 Hal 388-395.

Joyce, B., Weil, M., Calhoun, E. 2011. Models of Teaching, (edisi kedelapan). Yogyakarta: Pustaka Pelajar.

Panggabean, D.D,. 2012. Analisis Pemahaman Konsep Awal dan Kemampuan Berpikir Kritis Bidang Studi Fisika Menggunakan Model Pembelajaran Advance Organizer dan Model Pembelajaran Direct Instruction. Jurnal Online Pendidikan Fisika Vol. 1 No. 2 ISSN 2301-7651.

Panjaitan, M. 2013. Analsisis Pemahaman Konsep dan Kemampuan Pemecahan Masalah Fisika Dengan Menggunakan Model Pembelajaran Kooperatif Grup Investigasi dan Model Pembelajaran Langsung. Medan: Pascasarjana Universitas Negeri Medan.

Primarinda. 2012. Pengaruh Model Pembelajaran Cooperative Learning Tipe Group Investigation (GI) Terhadap Keterampilan Proses Sains dan Hasil Belajar Biologi Siswa Kelas X SMA Negeri 4 Surakarta Tahun Pelajaran 2011/ 2012. Jurnal Pendidikan Biologi Volume 4 Nomor 2 Hal. 60 71.

Rizal, M,. 2014. Pengaruh Pembelajaran Inkuiri Terbimbing dengan Multi Representasi Terhadap Keterampilan Proses Sains dan Penguasaan Konsep IPA Siswa SMP. Jurnal Pendidikan Sains Vol. 2 No. 3 Hal 159-165.

Rustaman, dkk. 2005. Strategi Belajar Mengajar Biologi. Malang: UM Press.

Suryosubroto, B. 2002. Proses Belajar Mengajar di Sekolah. Jakarta: Rineka Cipta.

Ulfa, A. 2014. Pengaruh Model Pembelajaran Group Investigation Terhadap Keterampilan Proses Sains Pada Materi Koloid di SMA. Pontianak:FMIPA Universitas Tanjungpura.

Wiranata, I., Sadia, I \& Suma, K. 2013. Pengaruh Model Pembelajaran Kooperatif Tipe Investigasi Kelompok (Group Investigation) Terhadap Keterampilan Proses dan Hasil Belajar Sains Siswa SMP. e-Journal Program Pascasarjana Universitas Pendidikan Ganesha Volume 3. 